\title{
プラズマ修飾ナノ微粒子のバイオ・医療応用
}

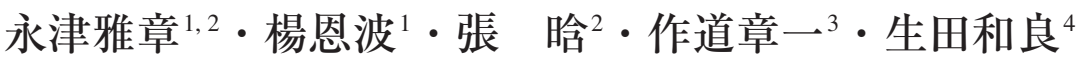 \\ 1静岡大学創造科学技術大学院 膈 432-8561 静岡県浜松市中区城北 3-5-1 \\ 2静岡大学大学院工学研究科 寀 432-8561 静岡県浜松市中区城北 3-5-1 \\ ${ }^{3}$ 琉球大学医学部 恶 903-0215 沖縄県中頭郡西原町上原 207 \\ ${ }^{4}$ 大阪大学微生物病研究所 齿 565-0871 大阪府吹田市山田丘 3-1
}

（2013 年 6 月 29 日受付； 2013 年 7 月 30 日掲載決定）

\section{Bio- and Medical-Application of Plasma-Functionalized Nanoparticles}

\author{
Masaaki NAGATSU ${ }^{1,2}$, Enbo YANG ${ }^{1}$, Han $\mathrm{CHO}^{2}$, Akikazu $\mathrm{SAKUdO}^{3}$ and Kazuyoshi IKUTA ${ }^{4}$
}

\begin{abstract}
${ }^{1}$ Shizuoka University, Graduate School of Science and Technology, 3-5-1 Johoku, Naka-ku, Hamamatsu, Shizuoka $432-8561$
${ }^{2}$ Shizuoka University, Graduate School of Engineering, 3-5-1 Johoku, Naka-ku, Hamamatsu, Shizuoka 432-8561

${ }^{3}$ University of the Ryukyus, Faculty of Medicine, 207 Uehara, Nishihara-cho, Nakagami-gun, Okinawa 903-0215

${ }^{4}$ Osaka University, Research Institute for Microbial Diseases, 3-1 Yamadaoka, Suita, Osaka 565-0871
\end{abstract}

(Received June 29, 2013 ; Accepted July 30, 2013)

\begin{abstract}
In the present study, we have carried out the study to understand the interaction between the plasma and nanostructured materials. The main research subjects are to fabricate nano-sized particles by using dc arc discharge, to modify their surfaces of nanoparticles or nano-structured materials by using plasma chemical modification, and to immobilize the biomolecules onto the surface of nanoparticles for bio- and medical application. Immobilization of the antibody of influenza virus onto the surface of aminated magnetic nanoparticles has been carried out for aiming at developing the feasibility of the selective detection of virus. The significant enhancement of condensation rate of influenza A type virus was confirmed by magnetic collection of antibody-immobilized magnetic nanoparticles. The result suggests a feasibility of the present method for selective influenza virus detection.
\end{abstract}

KEYWORDS : plasma chemical modification, magnetic nanoparticle, RF plasma, virus collection, medical application

\section{1.は じめに}

非熱平衡プラズマを用いたバイオ・医療分野への応用 に関する研究が, 近年注目されている。非熱平衡プラズ マを用いる大きな利点は, 低圧放電あるいは大気圧放電 のいずれにおいても, 対象物をほぼ常温に保ったまま, 生成された励起原子・分子による化学的反応プロセスを 実現できる点であり, さらに生成される電子やイオンな どの荷電粒子による基板表面での物理的相互作用，ある いは電子励起による原子・分子の紫外線発光による材料 表面の活性化を相乗的に活用できる点である。特に，バ イオ・医療分野における低温プロセスの実用化では，用

E-mail : tmnagat@ipc.shizuoka.ac.jp
途あるいは処理対象物は様々であるが，(1) 一般的に樹 脂などの対象物に熱的ダメージを与えないこと，（2）化 学薬品を用いたウエットプロセスと異なり環境に優しい こと, さらに（3）短時間で所望の効果を実現できるこ となどが実用化の観点から求められている。プラズマの バイオ・医療分野への応用では, 近年,「プラズマ医療 科学」と呼ばれるプラズマ科学と医学とを融合した新た な学際領域が国内外において注目され, 精力的に研究が 行われている。また，バイオ・医療分野に必要とされる 各種材料の生体適合性や血液凝固特性（あるいは逆に抗 凝固特性）などの様々な機能性を付加するためのプラズ マ表面処理に関する研究も，古くより行われている。

本稿では, 筆者らが医療分野への応用を目的としてこ れまで行ってきた, 大きさ数 $10 \mathrm{~nm} \sim 100 \mathrm{~nm}$ の磁性体 
ナノ微粒子を用いたプラズマ化学修飾，および多糖類等 のバイオ高分子の固定化など, バイオ・医療分野への応 用を目指した最近の研究成果について報告する。なお, 本稿の記載にあたり, 科学研究費・新学術領域研究「プ ラズマとナノ界面の相互作用に関する学術基盤の創成」 （代表; 白谷正治教授）において, 筆者らが担当した成 果報告書の記載を一部引用した ${ }^{1)} 。$

\section{2. プラズマ化学修飾による各種微粒子の表面} 機能化

近年，金や磁性体などのナノ微粒子の医療関係への応 用に関する研究が精力的に行われている ${ }^{2 \sim 10)}$ 。特に, 力 一ボン層によりカプセル化された鉄などの磁性体ナノ微 粒子は, 大気下において安定で酸化に強く, ドラッグ・ デリバリー・システム（Drug Delivery System; DDS）な どへの害用化が考えられている9)。

しかしながら，これらの微粒子の医療応用を可能にす るためには, ナノ微粒子の生体適合性や液体中での分散 性の向上が不可欠である。磁性ナノ微粒子を用いた DDS では, 一般に Fig. 1 のようにウイルスほどの大き さ（数 $10 \mathrm{~nm}$ 程度）の磁性体コアに, シリカあるいは ポリマー膜を被覆コーティングし, その表面に様々な薬 剤を付加して用いている。人間の体は, 体内に取り込ま れた物質の大きさが $3 \mathrm{~nm}$ より小さいものに対しては, 体が血液中の栄養を吸収するように自然に吸収したり排 出したりするように働き，逆に，極端に大きく, 400 $\mathrm{nm}$ 以上の大きさのものは異物として認識され, 分解し て排出されるといわれている。このことから, DDS で は，一般に 4〜 400 nm の大きさの微粒子を使い，血管 の中を循環させ患部へ導入する方法が考えられている。

本研究では, 直流アーク法により作製したグラフェン 層でカプセル化された磁性体ナノ微粒子を用い, $\mathrm{RF}$ 誘 導結合型プラズマを用いたナノ微粒子の表面化学修飾お よびその医療応用に関する害験を行った ${ }^{11,12) 。 ~}$

直流アーク放電により作製したグラフェン層でカプセ

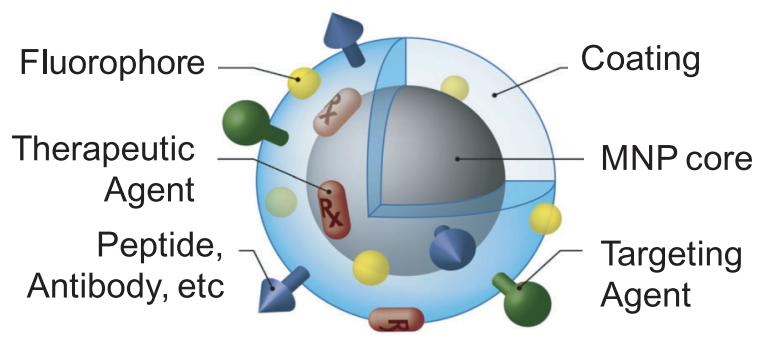

Fig. 1. (color online). Illustration of magnetic nanoparticle for medical application. ${ }^{9)}$
ル化された磁性体ナノ微粒子の高解像透過電子顕微鏡

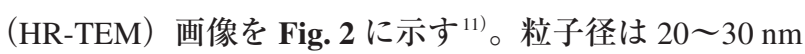
程度であり, コア部の鉄微粒子の周りにグラフェン層が 幾層も覆った構造であることがわかる。

Fig. 3 に作製した鉄ナノ微粒子の X 線回折法（XRD） による解析結果を示す ${ }^{11)}$ 。コア部の鉄結晶成分あるいは $\mathrm{Fe}_{3} \mathrm{C}$ 成分を示す $45^{\circ}$ 付近に見られるピークに加え, $26.6^{\circ}$ においてグラファイト成分を示す鋭いピークが確 認できる。また，炭化鉄あるいは酸化鉄成分の存在も確 認できる。さらに, エネルギー分散型 X 線分析による 元素マッピングの測定から, コア微粒子内部に酸素が含 まれていることを確認している11)

Fig. 4 はグラフェン層でカプセル化された鉄ナノ微粒 子の直流磁場による磁化特性の測定結果を示してい る ${ }^{12)}$ 。図からわかるように, 外部磁界を取り去った際

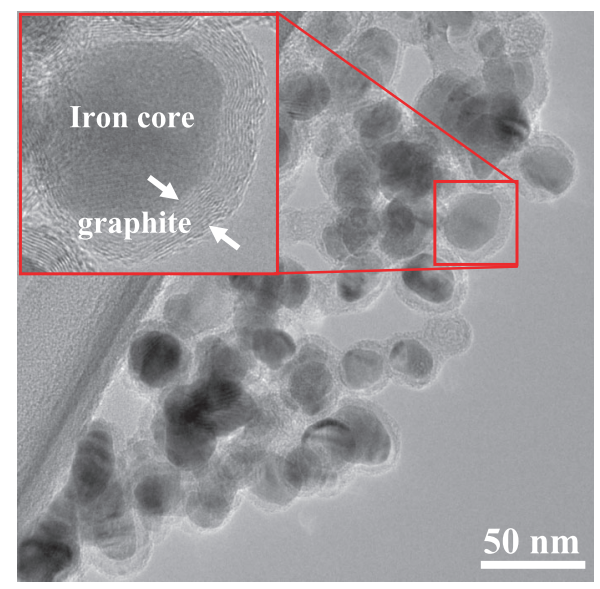

Fig. 2. (color online). HR-TEM image of magnetic nanoparticles. ${ }^{11)}$

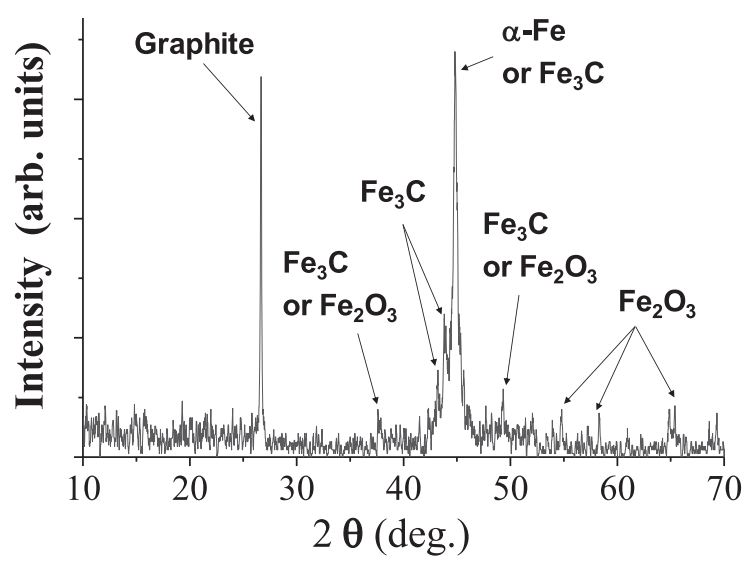

Fig. 3. XRD spectrum of graphite-encapsulated $\mathrm{Fe}$ nanoparticles. ${ }^{11)}$ 
に, 磁化はほぼゼロとなっており, DDS の磁性体微粒 子に必要とされる, いわゆる超常磁性の磁気特性を示し ている。

RF プラズマによる化学修飾を行った鉄ナノ微粒子の エタノール液中での分散特性の様子を Fig. 5 に示す。こ こで, サンプル A はプラズマ未処理の微粒子, サンプ ル B は直接 $\mathrm{NH}_{3}$ プラズマ処理した微粒子, サンプル C は前処理として Ar プラズマで 5 分間の処理を行った 後, $\mathrm{NH}_{3}$ プラズマで 1 分間のアミノ基修飾を行った微 粒子を示している。

処理した微粒子をエタノール溶液中に超音波洗浄器で

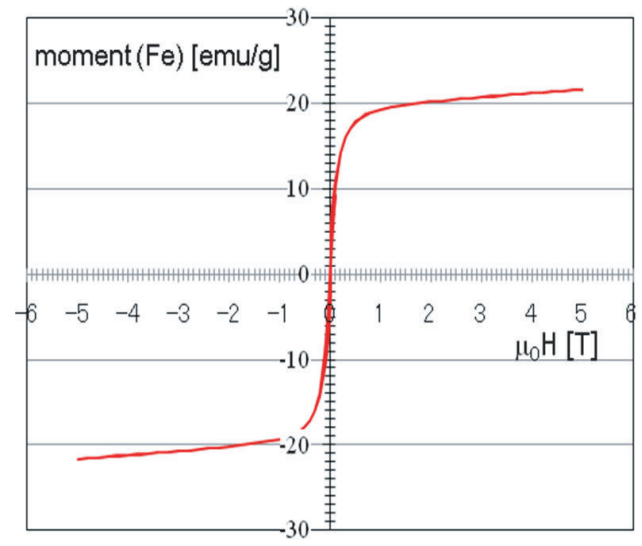

Fig. 4. (color online). Magnetic characteristics of magnetic iron nanoparticles (Courtesy of Prof. T. Kisu, Kyushu Univ.). ${ }^{12)}$

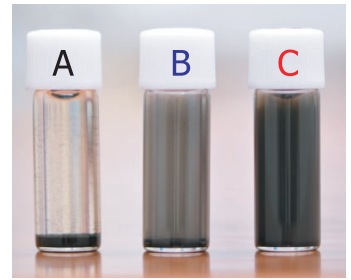

After 24 hours

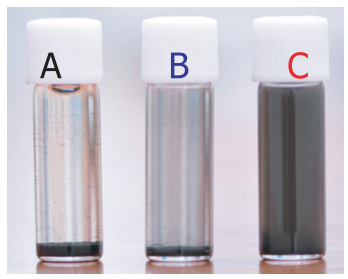

After 72 hours

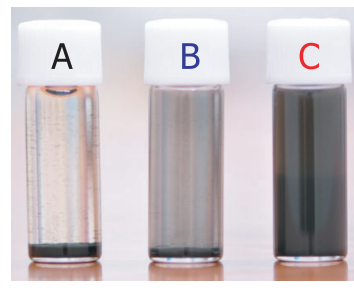

After 48 hours

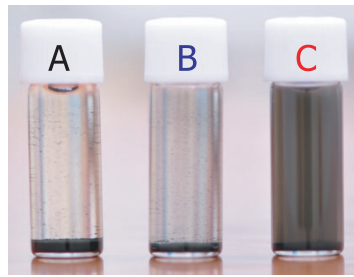

After 96 hours
Fig. 5. (color online). Comparison of dispersion characteristics of magnetic nanoparticles (A : untreated, $\mathrm{B}: \mathrm{NH}_{3}$ plasma only, $\mathrm{C}$ : Ar plasma pre-treatment $+\mathrm{NH}_{3}$ post-plasma treatment).
混ぜ合わせた後，24 時間から 96 時間経過したときの様 子を示しており，この結果から，サンプル C, すなわち $\mathrm{Ar}$ プラズマによる前処理を行った後, $\mathrm{NH}_{3}$ プラズマに よるアミノ基修飾した場合の方が, 直接 $\mathrm{NH}_{3}$ プラズマ 処理したサンプル B に比べて飛躍的に分散性が改善し ており，Arプラズマによるグラフェン層の前処理の効 果の重要性を示している。

\section{3. プラズマ化学修飾された微粒子表面への多 糖類の固定化}

前章で記述したアミノ基の表面修飾を施したグラフェ ン層外包鉄ナノ微粒子を用いて，デキストラン（Dextran）の固定化を行った ${ }^{12)}$ 。デキストランは，ショ糖を 原料として乳酸菌が生産する多糖類の一種で, グルコー スを唯一の構成成分とし, 医薬品, 化粧品, 写真フィル ムなど様々な用途に用いられている。Fig. 6 はデキスト ランを過ヨウ素酸ナトリウムで酸化してアルデヒド基を 導入した後, プラズマ化学修飾により磁性体微粒子表面 に添加したアミノ基と共有結合させる反応手順の概略を 示している。本実験では，デキストラン量を変化させた ときの磁性体ナノ微粒子表面のアミノ基がデキストラン 固定化に使われるかを調べることとした。

まず，デキストランによる固定化を行う前に，微粒子 表面に修飾したアミノ基の量を誘導体化法を用いて評価 し，次にデキストランを固定化した後に残ったアミノ基 の量を調べることにより，アミノ基と結合したデキスト

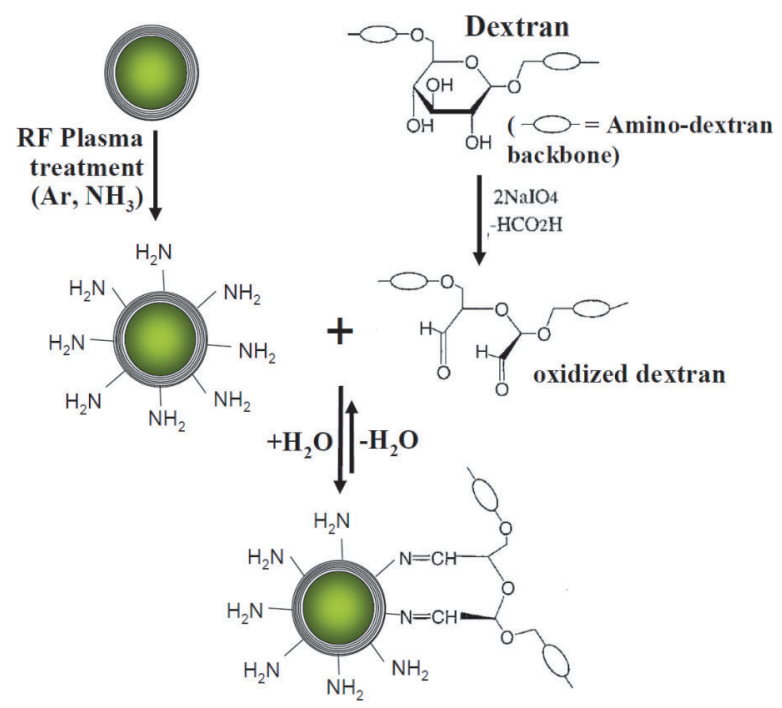

Fig. 6. (color online). Schematic illustration of plasma surface modification of nanoparticles by $\mathrm{Ar}$ and $\mathrm{NH}_{3}$ plasma and periodate oxidation of dextran by $\mathrm{NaIO}_{4}$ followed by covalent immobilization path of aldehyde groups of dextran onto the treated nanoparticles. ${ }^{12)}$ 
ラン量を評価した。誘導体化法によるアミノ基の評価で は，Fig. 7 に示したように，アミノ基を有するサンプル に 4-Trifluoromethyl benzaldehyde（TFBA）を反応させる ことにより，アミノ基 1 個がフッ素原子 3 個に置換され ることを利用し，XPS による $\mathrm{F}$ 原子の評価からアミノ 基の量を評価した。

Fig. 8 は，デキストランの量を $2.0 \mathrm{~g} / 100 \mathrm{ml}$ まで増加 させたときの，デキストラン固定化に使われたアミノ基 の変化を示している。アンモニアプラズマにより表面化 学修飾を行った微粒子表面のアミノ基数の定量には, 化 学的誘導体化法を用いた。化学的誘導体化法では, 化合 物の一部をほかの原子や原子団に置換して誘導体とする 手法である。本研究では, SPDP (Sulfosuccinimidyl 6[3-(2-pyridyldithio) propionamido] hexanoate) を用い, SPDP 溶液とアミノ基修飾グラフェン外包磁気ナノ微粒

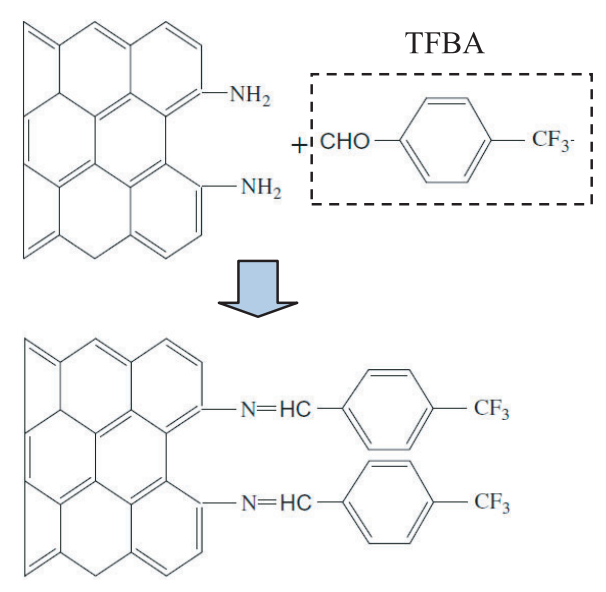

Fig. 7. (color online). Illustration of chemical derivertization method for measuring amino groups.

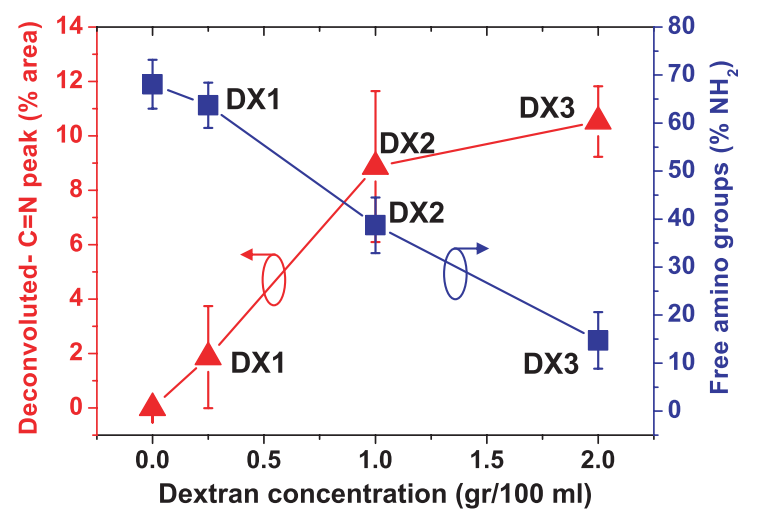

Fig. 8. (color online). The dependence of area percentage of $\mathrm{C}=\mathrm{N}$ peak taken from $\mathrm{N} 1 \mathrm{~s}$ XPS spectra before amino group derivatization and atomic percentage free amino groups estimated by chemical derivatization vs. dextran concentration. ${ }^{12)}$
子を反応させることで，一つのアミノ基に対して SPDP 分子を結合させた。

次に，SPDP 分子を結合させた微粒子にDTT（Dithiothreitol）溶液を加え反応させることによって, SPDP 分 子中の S-S 結合を切断し, SPDP 分子から Pyridine-2thione（P2T）分子を分離する。この $\mathrm{P} 2 \mathrm{~T}$ 分子の波長 $343 \mathrm{~nm}$ での吸光度を測定することによって, 溶液に含 まれる $\mathrm{P} 2 \mathrm{~T}$ 分子の量を評価することができる。 $\mathrm{P} 2 \mathrm{~T}$ 一 分子はアミノ基一つに対応するため, 使用した微粒子の 質量, 比重を事前に測定し, 総微粒子数で $\mathrm{P} 2 \mathrm{~T}$ 分子数 を割ることで一微粒子当たりのアミノ基数の算定が可能 となる。この方法を用いて吸光度解析を行った結果, 微 粒子 1 個当たりのアミノ基数として約 $2 \times 10^{4}$ 個が得ら れた。なお，微粒子を配置した金属基板ステージに負電 圧パルスを印加することにより，微粒子をプラズマ中に 導入する方法を用いることによって, 約 $8 \times 10^{4}$ 個にア ミノ基数を増加させることに成功している。この数値 は, 市販されている磁気ビーズに比べて 1 2 桁高い值 となっており, より高い修飾率のアミノ基添加を実現し ている。

\section{4. アミノ基修飾磁気ナノ微粒子を用いたイン フルエンザウイルスの濃縮化}

前章に扔けるグラフェン層外包磁気微粒子表面へのデ キストラン固定化実験の結果を踏まえ, 磁気微粒子のイ ンフルエンザウイルスなどの選択的回収, 高感度検出技 術の開発を目的として, Fig.9に示したようにウイルス を模擬した糖結合性タンパク質として ECA（Erythrina Cristagalli）レクチンを用い，微粒子に固定化する糖鎖 として LacNAc（N-acetyllactosamine）を用いて糖鎖固定 化の有無によるレクチン回収率を比較する予備実験を行 つた ${ }^{13)}$ 。

Fig. 10 にレクチンの回収率の測定結果を示す。 LacNAc 糖鎖を固定化していない磁気微粒子の場合に は，10〜15\% のレクチン回収率であるのに対して，糖 鎖を固定化した場合には $80 \%$ 程度の回収に成功してお り，きわめて高い回収率であることが示された。糖鎖を 固定していないサンプルの場合に扔いてもレクチンが結 合した原因は, 恐らく微粒子表面への直接的な凝集, 吸 着によるものと考えられる。

次に, アミノ基修飾を行った磁気ナノ微粒子にインフ ルエンザウイルス抗体を固定化した場合のウイルス濃縮 に関する研究を実施した。実験では, 磁性体ナノ微粒子 表面に修飾したアミノ基にインフルエンザウイルス抗体 である $\mathrm{C} 111$ を結合した。ここで, 抗体 $\mathrm{C} 111$ は, ウイ ルスのヘマグルチニンに選択的に結合する抗体であり， 


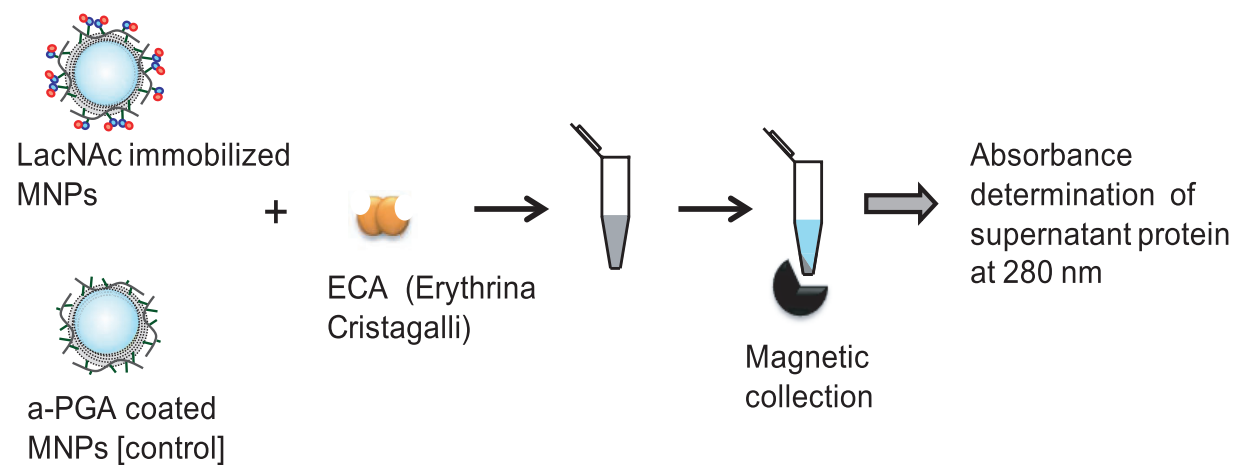

Fig. 9. (color online). Illustration of selective protein collection using MNPs. ${ }^{13)}$

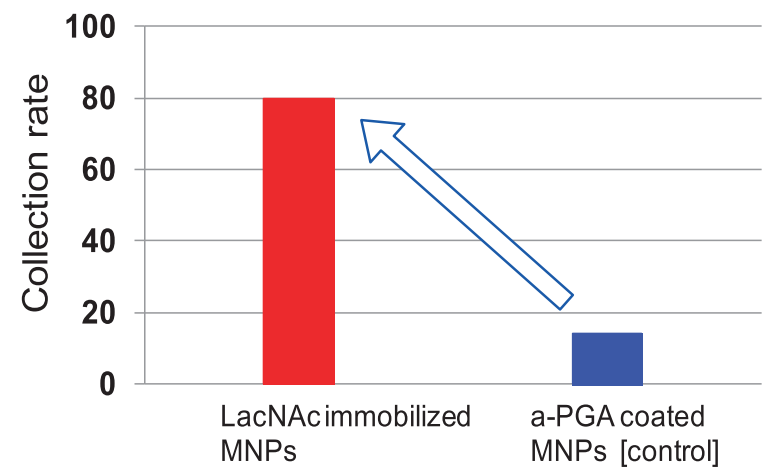

Fig. 10. (color online). Collection rate of ECA lectin by MNPs with and without immobilization of LacNAc sugar chain. ${ }^{13)}$

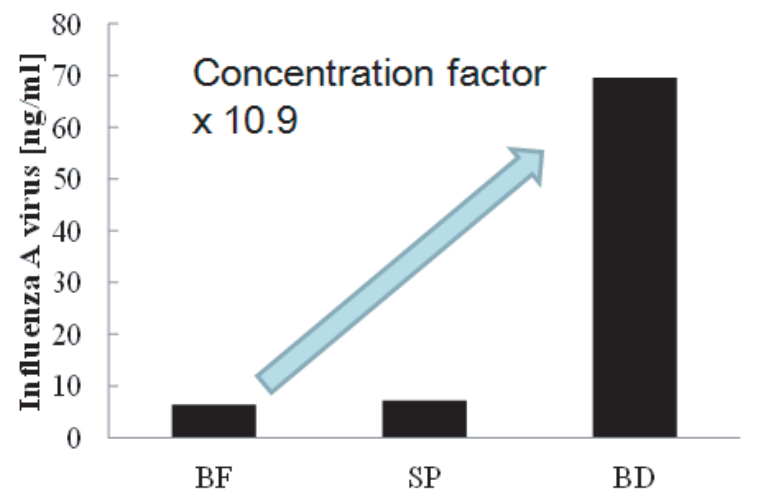

Fig. 12. (color online). Results of ELISA of virus condensation for samples using C111 antibody.

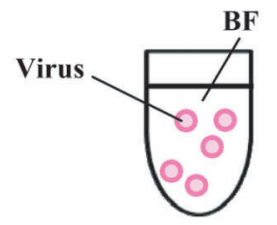

Virus -infected sample

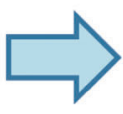

Incubated with magnetic beads
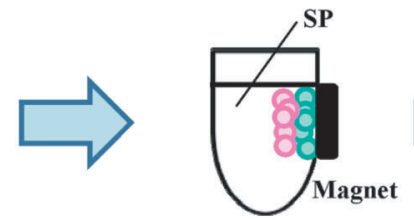

Magnetic separation

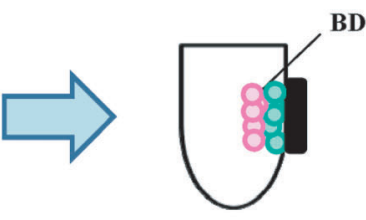

Discard supernatant and wash

Fig. 11. (color online). Procedure of magnetic collection of influenza virus by antibody-immobilized magnetic nanoparticles.

この抗体を用いてインフルエンザウイルスの濃縮率を調 ベた抗体結合磁気ナノ微粒子によるインフルエンザウイ ルス濃縮の手順を Fig. 11 に示す。インフルエンザウイ ルスを含んだサンプルを BF（濃縮前サンプル）とし， 抗体結合磁気ナノ微粒子と反応させた。さらに微粒子を 磁石により回収し, 回収後の溶液を SP (上清), 回収し た微粒子を BD（濃縮後サンプル）とした。

次に BF, SP, BD の各サンプルについて, $1 \mathrm{ml}$ 中に 含まれるインフルエンザウイルスの量を測定した。 C111 抗体を用いた場合の測定結果を Fig. 12 に示す。
BF, SP は約 $6.2 \mathrm{ng} / \mathrm{ml}$ に対し, BD は約 $70 \mathrm{ng} / \mathrm{ml}$ であ り, BF に対する BD の濃縮率はおよそ 10.9 倍であっ た。表面修飾したアミノ基に結合した抗体により，イン フルエンザウイルスが抗原抗体反応で結合し, 磁気回収 によりウイルスの濃縮が可能になった結果である。

また抗体 C111に対してサンプルの PCR 解析を行っ た結果から, ウイルスの DNA 成分が SP 部分では検出 されていないが, 磁気回収したサンプル BD では検出が 確認できたことから, 改めて本手法によるウイルスの磁 気回収による濃縮化が達成できていることを示してい 
る。

本研究によるウイルス回収㧍よび高濃縮化の達成によ り，イムノクロマトグラフィーや PCR などの既存の検 出法へサンプルを供する前に, 本手法によりインフルエ ンザウイルスの濃縮を行うことで感度や確度を向上させ ることが可能になるものと期待される。また, 最近の研 究結果から, 本手法により生きたままウイルスを回収, 増殖することにも成功しており, 将来的なワクチン製造 への展開の可能性が大いに期待される。

\section{5. 終わりに}

本研究では, 磁性体ナノ微粒子のバイオ・医療分野へ の応用を目的とし, プラズマと微粒子との物理的・化学 的表面相互作用, さらに RF プラズマによる微粒子表面 の機能性付加, ナノサイズ境界面を有する微粒子とプラ ズマとの表面相互作用に関する研究を行った。また, RF プラズマによるグラフェン外包鉄ナノ微粒子の表面 化学修飾，およびその表面にデキストランなどの多糖 類, あるいはウイルスを模擬したタンパク質に選択的に 結合する糖鎖の固定化実験を行い，その効果を明らかに した。さらに, RF プラズマによりアミノ基修飾を行っ た磁性体ナノ微粒子の表面に, インフルエンザウイルス 抗体を固定化し, 磁気回収によるウイルスの濃縮効果を 確認する検証実験を行った。実験結果は，10 倍以上の 濃縮回収を示しており, インフルエンザウイルスの選択 的回収システムあるいは高速検出システムへの展開の可 能性を示す結果となっている。今後は, ウイルス回収 率・濃縮率のさらなる改善を図るとともに, ほかのウイ ルスについても本手法の適用の可能性を調べていく予定 である。

\section{謝 辞}

本研究は, 文部科学省科学研究費新学術領域研究「プ ラズマとナノ界面の相互作用に関する学術基盤の創成」 (代表者：白谷正治教授）の計画研究「プラズマプロセ スによる微粒子ミクロ表面のバイオ活性制御技術の開発
と医療応用」の採択をいただき，平成 21 年度より行っ たもので，これまでの支援に厚く謝意を表します。ま た, 本研究において作製した磁性体ナノ微粒子の磁気測 定に多大なるご協力をいただきました九州大学工学研究 科の木須隆啺教授に梁く感謝いたします。本研究におけ る磁性体ナノ微粒子の糖鎖固定化実験でご協力いただい た, 静岡大学農学部碓氷泰市教授, 創造科学技術大学院 朴龍洙教授および尾形慎助教に厚く謝意を表します。ま た, 日頃, 実験で協力いただいた研究室の大学院生諸氏 に感謝します。

\section{文献}

1) 永津雅章: 文部科学省新学術領域研究計画研究「プ ラズマプロセスによる微粒子ミクロ表面のバイオ活 性制御技術の開発と医療応用」平成 $22-24$ 年度成果 報告書 $(2011 ， 2012 ， 2013)$.

2) Q.A. Pankhurst, N.K.T. Thanh, S.K. Jones and J. Dobson : J. Phys. D : Appl. Phys. 42, 224001 (2009).

3) Q.A. Pankhurst, J. Connolly, S.K. Jones and J. Dobson : J. Phys. D : Appl. Phys. 36, R167 (2003).

4) A-H. Lu, E.L. Salabas and F. Schuth : Angew. Chem., Int. Ed. 46, 1222 (2007).

5) S. Kim, E. Shibata, R. Sergiienko and T. Nakamura: Carbon 46, 1523 (2008).

6) A. Ito, M. Shinkai, H. Honda and T. Kobayashi : J. Biosci. Bioeng. 100, 1 (2005).

7) C.C. Berry and A.S.G. Curtis : J. Phys. D : Appl. Phys. 36, R198 (2003).

8) C.C. Berry : J. Phys. D : Appl. Phys. 42, 224003 (2009).

9) M. Bystrzejewski, S. Cudzilo, A. Huczko, H. Lange, G. Soucy, G. Cota-Sanchez and W. Kaszuwara : Biomol. Eng. 24, 555 (2007).

10) C. Sun, J.S.H. Lee and M.Q. Zhang : Adv. Drug Delivery Rev. 60, 1252 (2008).

11) T.E. Saraswati, T. Matsuda, A. Ogino and M. Nagatsu : Diamond Relat. Mater. 20, 359 (2011).

12) T.E. Saraswati, A. Ogino and M. Nagatsu : Carbon 50, 1253 (2012).

13) M. Nagatsu, R.V. Bekarevich, A. Balmakov, I. Motrescu, A. Ogino, A. Murakawa and E.Y. Park : MRS Online Proc. Libr. (2012) p. 1469. 